\title{
Reform and revolution in South America: a forum on Bolivia and Venezuela
}

\author{
Pamela Calla $\cdot$ Steve Striffler
}

Published online: 15 September 2011

(C) Springer Science+Business Media B.V. 2011

Hugo Chavez and Evo Morales represent something of a conundrum for the Left. The right-wing opposition has been so fierce, so deceitful, so excessive, and so powerful, the Left has often felt the need to unconditionally defend the governments, policies, and even personas of Hugo Chavez and Evo Morales. At times, this has been a necessary stance. Though significant gains have been made under the governments of Hugo Chavez and Evo Morales (in terms of poverty reduction, access to health care, education, etc.), there remains a considerable gap between rhetorical claims of "participatory democracy," socialism, and noncapitalist development, in contrast to the reality of policies and practices that undermine the autonomous political mobilization, and/or economic interests, of popular sectors. Where does this leave the Left? From what Left-position, both intellectually and politically, does one launch a critique of Chavez, Morales, and their followers without joining a right-wing opposition that is nostalgic for neoliberalism and is using the rhetoric and practice of formal democracy?

The following contributions provide a critical Left assessment of the "revolutionary" process under the Chavez and Morales governments. Many different topics are addressed, but collectively, the essays center on two sets of questions. First, and most basically, how have popular groups, including indigenous peoples, peasants, workers, women, and others who have been historically marginalized and disenfranchised, benefitted from the rise of "revolutionary" governments in Bolivia and Venezuela? What have these governments promised? What have they delivered? Where have they fallen short? Second, what is the relationship between the state and popular political and cultural mobilization and expression? What has

P. Calla

New York University, Manhattan, NY, USA

e-mail: pc1210@nyu.edu

S. Striffler $(\bowtie)$

University of New Orleans, New Orleans, LA, USA

e-mail: sstriffl@uno.edu 
been the relationship between means and ends? And what does all this say about the relationship between socialism and democratic processes? As we will see, these questions are intimately related. The extent to which these revolutionary governments have followed through on their promises and programs, in effect deepening or undermining the revolutionary process, is closely connected to how, to what extent, and with what effectiveness popular groups have mobilized and demanded that the revolution be implemented.

What is clear from the articles is that both revolutionary processes have brought significant benefits, in terms of economic progress and access to political power, to previously marginalized groups; these gains are real, but thus far remain insufficient, inconsistent, contradictory, and often imposed from above, in effect controlling, silencing, and fragmenting popular movements; and although there are broad similarities between the two governments, the processes of revolutionary change both in origin and in practice look quite different in Bolivia and Venezuela. All revolutions have a different history.

Venezuela, as Forest Hylton and Steve Ellner point out in their essays, is significantly different from Bolivia (and most other revolutions) in at least two important respects. First, although Chavez came to power with widespread support, he was not put into the office by powerful, highly mobilized, and well-organized social movements. To the contrary, his election, his presidency, his government empowered popular movements and created political spaces for them to develop, even flourish. This, in turn, allowed for the second, and most distinguishing, feature of the Boliviarian Revolution, namely its continual, if uneven, radicalization over time. Emboldened and (then) pushed by popular movements that the Chavez government has helped to develop and integrate into state power, the Bolivarian Revolution has been able to defeat (or at least contain) the Venezuelan right, while securing and deepening the revolution along a number of lines (see Ellner for an excellent description and analysis of this process). As Naomi Schiller's look at popular media makes clear, the dialectical engagement between state agents and social movement actors distinguishes Venezuela, whereby a differentiated state becomes a multi-sited arena of participatory democratic struggle, from virtually every country in the hemisphere. This process has not been without its contradictions and shortcomings, as Daisy Barreto's essay on Venezuelan indigenous peoples, and Angela Marino's exploration of a cultural arts organization highlight, but it has brought about profound changes in Venezuela's political, economic, and social landscape.

By contrast, Morales was brought to power in Bolivia by popular forces, including most notably indigenous groups, peasants, and workers, with the express purpose of dismantling neoliberalism and redesigning the Bolivian state and its political economy. His was a radical mandate. Once in power, however, as Hylton points out, Morales pursued a strategy almost the opposite of Chavez. Because he feared that mobilizing his base even further would antagonize a debilitated, yet dangerous, right, Bolivia has seen popular social movements weaken, the right rebound, and the possibility of implementing a deeper revolution undermined. Although "revolution" still animates Morales and his administration at the level of rhetoric, the Bolivian government practices a limited brand of state-based 
reformism that has yielded relatively modest achievements. Raquel Gutierrez goes even further and highlights how the Bolivian government gradually privileged "traditional" forms of representation (i.e., party politics), sugar coated with different labels like, "twenty-first century socialism," or, Bolivian "plurinationalism," and a political economy that is now acting in the interests of multinational corporations, much as with past governments but now couched in a revolutionary rhetoric designed to disguise this reality. In the process, the Morales' administration, she affirms, ignored or denigrated the logic and form of what brought him to power in the first place: communitarian popular politics. This, as Nicole Fabricant shows in her essay, puts Bolivian leftists in a difficult position, reluctant to directly, openly, and robustly oppose Morales, they find themselves waiting for reforms that may never come or seem destined to disappoint. As she writes: "How can movements realign their interests, separate their immediate aspirations from state politics and reconstruct their radical project?" How, in other words, can the Left reconstitute itself, taking into consideration the lessons learned from both processes of change? Bolivians are hardly alone in asking this pressing question. 